\title{
Conformations and Mitochondria1 Uncoupling Activity of Synthetic Emerimicin Fragments
}

\author{
P. ANTONY RAJ, MANOJ K. DAS, and P. BALARAM,* Molecular \\ Biophysics Unit, Indian Institute of Science, Bangalore 560 012, India
}

\begin{abstract}
Synopsis
Several amino terminal fragments of the emerimicins (Ac-Phe ${ }^{1}-\mathrm{Aib}^{2} \cdot \mathrm{Aib}^{3} \cdot \mathrm{Aib}^{4}-\mathrm{Val}^{5}-\mathrm{Gly}^{6}-\mathrm{Leu}^{7}$. $\mathrm{Aib}^{8}-\mathrm{Aib}^{9}-\mathrm{Hyp}^{10}-\mathrm{Gln}^{11}-\mathrm{D}-\mathrm{Iva}^{12}-\mathrm{Hyp}^{13}-\mathrm{Ala} / \mathrm{Aib}^{14}-\mathrm{Phol}^{15}$ ) ranging in length from five to ten residues have been synthesized. Nuclear magnetic resonance studies have been carried out on the 1-5, 6-10, $1-6,1-7,1-8,1-9$, and 1-10 fragments. The number of solvent-shielded $\mathrm{NH}$ groups in $\mathrm{CDCl}_{3}$ solutions for $1-5,1-6,1-7,1-8,1-9$, and 1-10indicate that $3_{10}$-helical structures are favored in this solvent. In $\left(\mathrm{CD}_{3}\right)_{2} \mathrm{SO}$, an additional $\mathrm{NH}$ group, assigned to $\mathrm{Aib}(3) \mathrm{NH}$ is solvent exposed in the fragments longer than six residues, suggesting partial unfolding of the N-terminal \#?-turn or transition to an a-helical conformation. The data for fragment 6-10 are consistent with a conformation having a single Leu-Aib \#?-turn.Infrared studies suggest an increase in the number of intramolecular hydrogen bonds with increasing peptide chain length. Appreciablemitochondrial uncoupling activity is observed for peptides with a chain length of at least seven residues. The order of efficiencies of the fragments is $1-7<1-8-1-10<1-9$, with the decapeptide exhibiting anomalously low uncoupling activity.
\end{abstract}

\section{INTRODUCTION}

The emerimicins are short peptides rich in $\alpha$-aminoisobutyric acid (Aib) produced by Emericellopsis microspora. ${ }^{1}$ The primary sequence of the emerimicins $^{2}$ resembles several other membrane-modifying fungal peptides of which alamethicin is the most extensively studied (see Fig. 1 for sequences). While considerable attention has been focused on the chemistry, conformation, and biological activity of alamethicin, ${ }^{3-10}$ there have been very few reported studies on the emerimicins. A preliminary report on the synthesis of emerimicin fragments has appeared." Also, crystal structures of the emerimicin fragments ranging in length from four to eight residues have been reported. ${ }^{12-15}$ Spectroscopic studies in solution have been reported on $\mathrm{N}$. terminal fragments lacking the L-Phe residue. ${ }^{16,17}$ Fluorescence methods have been used to monitor aqueous phase aggregation of fluorescent synthetic fragments." There have been no detailed reports on the channel-forming ability of emerimicins, although reference has been made to the ability of the natural peptides to form pores in synthetic lipid bilayers (see footnote in Ref. 2). We describe in this report the synthesis of amino-terminal fragments of emerimicin including the $\mathrm{N}$-terminal decapeptide. The membrane-modifying activity of these peptides is compared by their ability to uncouple oxidative

\footnotetext{
*To whom correspondence should be addressed.
} 

Alamethicin I (II)
Ac-Aib-Pro-Aib-Ala-Aib-Ala (Aib)-GIn-Aib-Val-Aib-Gly-Leu - A ib-Pro-Val-Aib-Aib-Glu-Gln-Phol
Emerimicin III(IV) Ac-Phe-Aib-Aib-Aib-Val-Gly-Leu-Aib-Aib-Hyp-Gin-D-IVa- Hyp-Ala (Aib) - Phol
Antiamoebin I(II) Ph-Phe-Aib-Aib-Aib-D-Iva-Gly-Leu-Aib-Aib-Hyp-GIn-D-1 - Hyp (Pro)-Aib-Pro-Phol
Zervamicin IIA(IIB) Ac-Trp-Ile-GIn-Aib(Iva)-Ile-Thr-Aib-Leu-Aib-Hyp-Gln-Aib- Hyp-Aib- Pro-Phol

Fig. 1. Sequences of some Aib-containing membrane-modifying peptides.

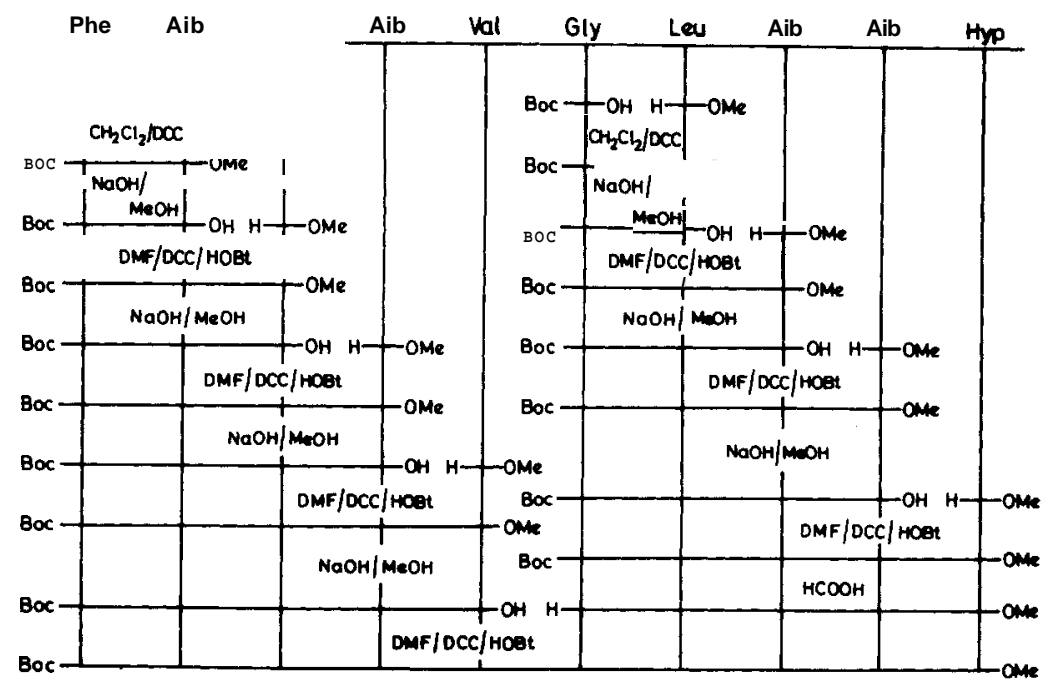

Fig. 2. The scheme for the synthesis of the peptides Boc-Phe-(Aib) $)_{3}$-Val-OMe $\left(\mathrm{E}_{1-5}\right)$, Boc-GlyLeu-Aib-Aib-Hyp-OMe $\left(\mathrm{E}_{6-10}\right)$, and Boc-Phe-(Aib) $)_{3}$-Val-Gly-Leu-Aib-Aib-Hyp-OMe $\left(\mathrm{E}_{1-10}\right)$.

phosphorylation. A systematic investigation of the solution conformation of these peptides using $270-\mathrm{MHz}$ 'H-nmr and ir studies is also described. The results establish highly folded helical conformations for these fragments, with appreciable uncoupling activity detected for peptides having a chain length greater than seven residues.

\section{EXPERIMENTAL}

Figure 2 illustrates the scheme adopted for the synthesis of 1-5 $\left(\mathrm{E}_{1-5}\right), 6-10$ $\left(\mathrm{E}_{6-10}\right)$, and 1-10 ( $\left.\mathrm{E}_{1-10}\right)$ emerimicin fragments. The peptides $\mathrm{E}_{1-6}$ (Boc-PheAib-Aib-Aib-Val-Gly-OMe), $\mathrm{E}_{1-7}$ (Boc-Phe-Aib-Aib-Aib-Val-Gly-Ieu-OMe)， $\mathrm{E}_{1.8}$ (Boc-Phe-Aib-Aib-Aib-Val-Gly-Leu-Aib-OMe), and $\mathrm{E}_{1-9}$ (Boc-Phe-AibAib-Aib-Val-Gly-Leu-Aib-Aib-OMe)were obtained by coupling Gly-OMe, GlyLeu-OMe, Gly-Leu-Aib-OMe, and Gly-Leu-Aib-Aib-OMe to the free acid of peptide $\mathrm{E}_{1-5}$, respectively. The coupling and work-up procedures are similar to those described earlier for model Aib peptides and have been described in detail elsewhere. ${ }^{19,20}$ The peptides were purified by silica gel column chromatography and checked for homogeneity by high performance liquid chromatography (HPLC) on a reverse-phase RP-18 Lichrosorb column, using 


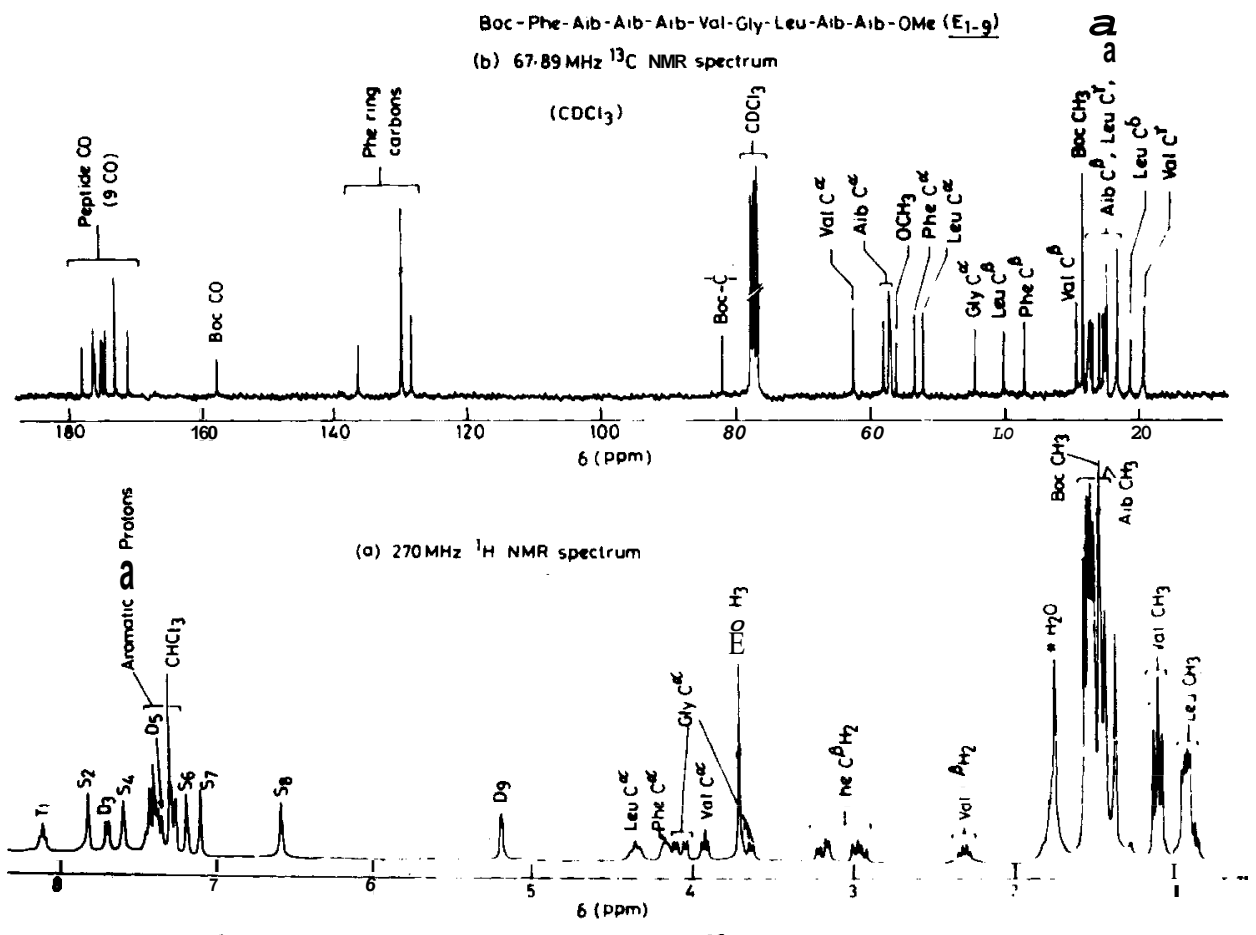

Fig. 3. (a) ${ }^{1} \mathrm{H}$-nmr (270-MHz) spectrum and (b) ${ }^{13} \mathrm{C}-\mathrm{nmr}(67.89-\mathrm{MHz})$ of $\mathrm{E}_{1-9}$ in $\mathrm{CDCl}_{3}$. Relevant ${ }^{13} \mathrm{C}$ chemical shifts $(\delta, \mathrm{ppm}$ downfield from tetramethylsilane) are $\mathrm{CO}$ 178.2, 176.6, 176.2, 175.2, 175.0, 174.6, 173.0, (2C), 157.6 (Boc CO); Phe $C_{1}$ 136.4, $C_{2}, C_{6}$ 130.0, $C_{3}, C_{5}, 128.4$; Boc C 82.0; Val C" 62.4; Aib $C^{\alpha}, \mathrm{OCH}_{3}$, 58.4,57.6-56.8(6C); Phe $\mathrm{C}^{\alpha} 53.4$; Leu $\mathrm{C}^{\alpha} 52.2$; Gly $\mathrm{C}^{\alpha} 44.6$; Leu

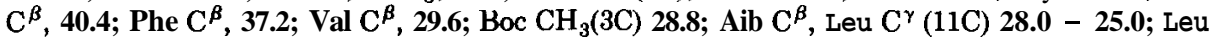
$C^{\delta}$, Val $C^{\gamma}$ (4C) 23.6, 21.6, 19.2.

methanol-water linear gradient elution, employing an LKB HPLC system (70-958 MeOH in $25 \mathrm{~min}$, flow rate $0.8 \mathrm{~mL} \mathrm{~min}^{-1}$ ). Peptides were fully characterized by amino acid analysis, $270-\mathrm{MHz}{ }^{1} \mathrm{H}-$ and $67.89 \cdot \mathrm{MHz}{ }^{13} \mathrm{C}-\mathrm{nmr}$ spectra. Representative spectra for the nonpeptide $\mathbf{E}_{1-9}$ are illustrated in Fig. 3. Table I summarizes the relevant analytical data for the synthetic fragments. HPLC analysis and ${ }^{13} \mathbf{C}-\mathbf{n m r}$ data established the absence of diastereomeric peptide contaminants in the purified products.

${ }^{1} \mathrm{H}$-nmr spectra were recorded on a Bruker WH-270 Fourier transform nmr spectrometer, equipped with an Aspect 2000 computer at the Sophisticated Instruments Facility, Indian Institute of Science, Bangalore. In the difference nuclear Overhauser effect (NOE) experiments, the perturbed and normal spectra recorded sequentially (one on-resonance and one off-resonance) in different parts of the memory ( $8 \mathrm{~K}$ of each) were obtained by low-power on-resonance saturation of a peak and by off-resonance shifting of the irradiation frequency, respectively. ${ }^{21}$ About 128 transients were accumulated with a relaxation delay of $3 \mathrm{~s}$ between transients to facilitate buildup of initial magnetization. Delineation of hydrogen-bonded NH groups was carried out as described earlier. ${ }^{22}$

Peptide effects on respiration of rat liver mitochondria were monitored with a Hansatech oxygen electrode as described earlier. ${ }^{23}$ 
TABLE I

Analytical Data for Emerimicin Fragments

\begin{tabular}{|c|c|c|c|c|c|c|c|c|}
\hline \multirow[b]{2}{*}{ Peptide $^{a}$} & \multicolumn{6}{|c|}{ Amino Acid Analysis ${ }^{\mathrm{b}}$} & \multirow{2}{*}{$\begin{array}{l}\text { Melting } \\
\text { Point }\left({ }^{\circ} \mathrm{C}\right)\end{array}$} & \multirow{2}{*}{$\begin{array}{l}\text { HPLC Retention } \\
\text { Time (min)' }\end{array}$} \\
\hline & Phe & Aib & Val & Gly & Leu & Hyp & & \\
\hline$E_{1-5}$ & $\begin{array}{c}1.0 \\
(1)\end{array}$ & $\begin{array}{c}2.92 \\
(3)\end{array}$ & $\begin{array}{c}1.1 \\
(1)\end{array}$ & - & - & - & 147 & 14.3 \\
\hline$E_{6-10}$ & - & $\begin{array}{l}2.0 \\
(2)\end{array}$ & - & $\begin{array}{l}1.1 \\
(1)\end{array}$ & $\begin{array}{l}1.0 \\
(1)\end{array}$ & $\begin{array}{c}0.92 \\
(1)\end{array}$ & 76 & 6.7 \\
\hline$E_{1.6}$ & $\begin{array}{l}0.98 \\
(1)\end{array}$ & $\begin{array}{l}3.02 \\
(3)\end{array}$ & $\begin{array}{l}1.0 \\
(1)\end{array}$ & $\begin{array}{l}1.0 \\
(1)\end{array}$ & - & - & 163 & 13.9 \\
\hline$E_{1-7}$ & $\begin{array}{l}0.87 \\
(1)\end{array}$ & $\begin{array}{l}3.15 \\
(3)\end{array}$ & $\begin{array}{l}0.94 \\
(1)\end{array}$ & $\begin{array}{l}1.1 \\
(1)\end{array}$ & $\begin{array}{c}0.97 \\
(1)\end{array}$ & - & 83 & 18.6 \\
\hline $\mathbf{E}_{1-8}$ & $\begin{array}{l}0.99 \\
(1)\end{array}$ & $\begin{array}{l}3.96 \\
(4)\end{array}$ & $\begin{array}{l}1.0 \\
(1)\end{array}$ & $\begin{array}{l}1.04 \\
(1)\end{array}$ & $\begin{array}{c}1.0 \\
(1)\end{array}$ & - & 112 & 19.8 \\
\hline$E_{1-9}$ & $\begin{array}{l}0.98 \\
(1)\end{array}$ & $\begin{array}{l}4.95 \\
(5)\end{array}$ & $\begin{array}{l}1.0 \\
(1)\end{array}$ & $\begin{array}{l}1.05 \\
(1)\end{array}$ & $\begin{array}{c}1.02 \\
(1)\end{array}$ & - & 125 & 20.7 \\
\hline $\mathbf{E}_{1-10}$ & $\begin{array}{c}0.97 \\
(1)\end{array}$ & $\begin{array}{l}5.0 \\
(5)\end{array}$ & $\begin{array}{l}0.98 \\
(1)\end{array}$ & $\begin{array}{c}1.03 \\
(1)\end{array}$ & $\begin{array}{l}1.02 \\
(1)\end{array}$ & $\begin{array}{l}0.83 \\
(1)\end{array}$ & 201 & 19.3 \\
\hline
\end{tabular}

${ }^{a}$ Peptides are $E_{1.5}$, Boc-Phe-Aib-Aib-Aib-Val-OMe; $E_{6-10}$, Boc-Gly-Leu-Aib-Aib-Hyp-OMe; $E_{1,6}$, Boc-Phe-Aib-Aib-Aib-Val-Gly-OMe; $E_{1-7}$, Boc-Phe-AibAib-Aib-Val-Gly-Leu-OMe; E ${ }_{1.8}$, Boc-Phe-Aib-Aib-Aib-Val-Gly-Leu-Aib-OMe; E ${ }_{1.9}$, Boc-Phe-Aib-Aib-Aib-Val-Gly-Leu-Aib-Aib-OMe; E 1 , Boc-Phe-AibAib-Aib-Val-Gly-Leu-Aib-Aib-Hyp-OMe.

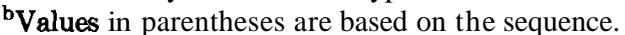

${ }^{c} \mathrm{HPLC}$ retention times were determined using a methanol-water gradient of $70-95 \% \mathrm{MeOH}$ in $25 \mathrm{~min}$. Flow rate $0.8 \mathrm{~mL}$ min ${ }^{-1}$. 


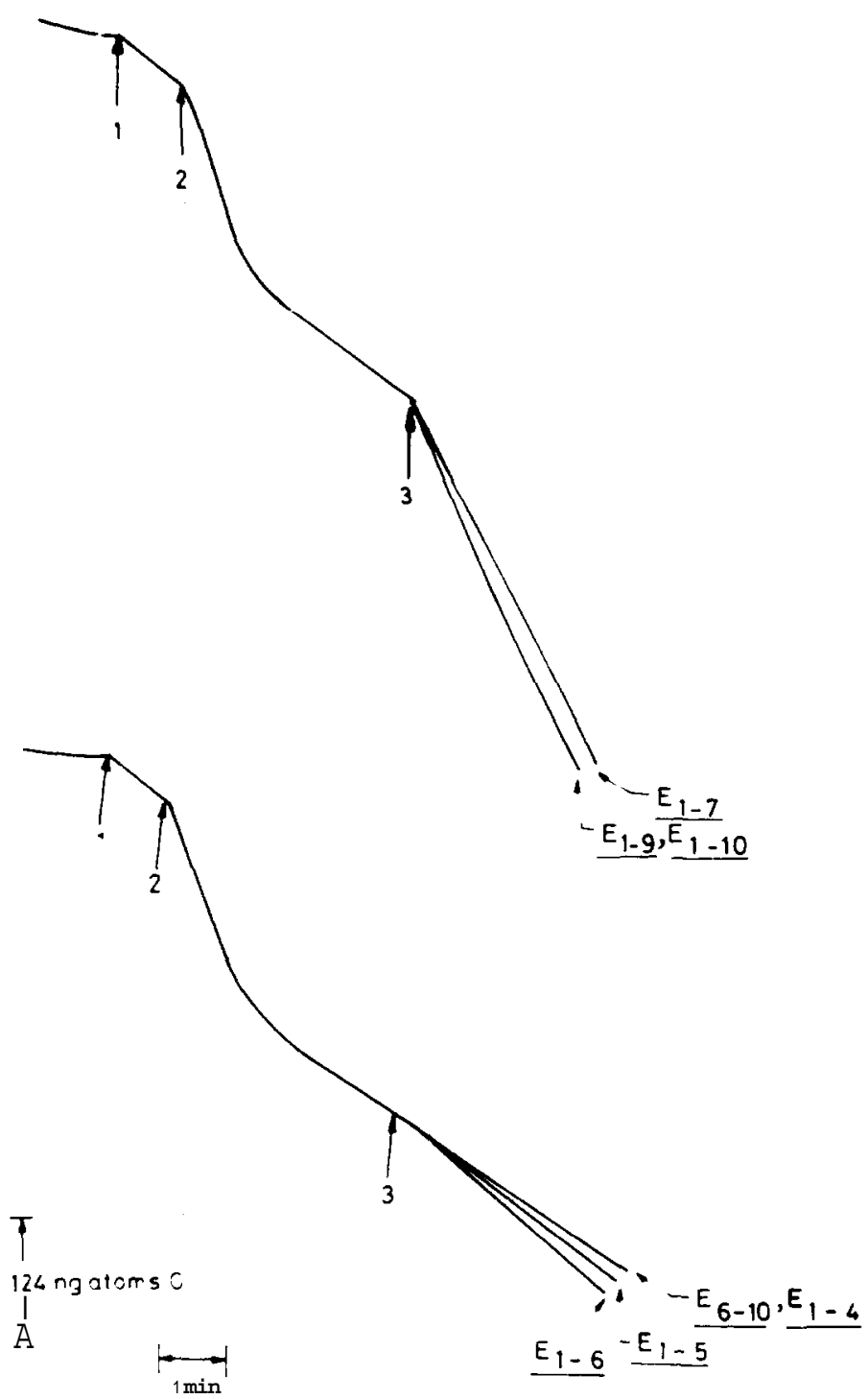

Fig. 4. Effect of synthetic fragments of emerimicin on state 4 respiration in rat liver mitochondria. Points 1,2 , and 3 indicate addition of succinate $(7.5 \mathrm{~m} M)$, ADP $(127 \mu M)$, and peptide $(50 \mu M)$, respectively.

\section{RESULTS AND DISCUSSION}

\section{Mitochondrial Uncoupling Activity}

Figure 4 shows the effect of addition of the various emerimicin fragments on the rate of oxygen consumption by state 4 mitochondria. The peptides are compared at a concentration of $50 \mu \mathrm{M}$. A minimum length of seven residues is essential for the peptide to stimulate state 4 respiration in mitochondria. The shorter fragments up to a chain length of six residues did not appreciably stimulate state 4 respiration. Addition of the longer amino terminal fragments 
from heptapeptide to decapeptide did result in a significant increase in the rate of oxygen consumption, suggesting that these peptides do exhibit some uncoupling effect. The activity appears to increase with increasing chain length, with the exception of peptide $\mathrm{E}_{1-10}$.

The dependence of the extent of uncoupling on the peptide concentration was assayed for each fragment and the $\phi_{1 / 2}$ value (concentration for half-maximal activity per milligram of mitochondrial protein) was computed from the double reciprocal plots of [peptide] ${ }^{-1}$ vs $\%$ decrease in respiratory control index-'. The $\phi_{1 / 2}$ values are (nmoles per mg protein) $\mathrm{E}_{1-7} 69, \mathrm{E}_{1-8} 33.3, \mathrm{E}_{1-9}$ 5.0, and $\mathrm{E}_{1-10}$ 35.7. These $\phi_{1 / 2}$ values establish that the effectiveness of the peptides as mitochondrial uncouplers increases with the chain length, when fragments $\mathrm{E}_{1-7}, \mathrm{E}_{1-8}$, and $\mathrm{E}_{1.9}$ are compared. A particularly interesting feature of the data is the anomalously low uncoupling activity observed for $\mathrm{E}_{1-10}$. This observation has been confirmed by independent $\phi_{1 / 2}$ determinations on different mitochondrial preparations. It is interesting to speculate that the terminal Hyp residue in $\mathbf{E}_{1-10}$ may impede the formation of functional channels by association of appropriately positioned peptide molecules.

\section{Conformational Studies}

In all the peptides studied, the Aib NH resonances appear as singlets and are not a priori assigned to specific residues in the sequence. However, a distinction can be made after delineating hydrogen-bonded $\mathrm{NH}$ groups on the basis of conformational arguments, as described later. The Phe NH resonance was assigned to the doublet resonance at high field (urethane NH). The Gly $\mathrm{NH}$ was assigned to the lone triplet resonance. The Val NH was assigned by spin-decoupling experiments, establishing the $\mathrm{NH} \leftrightarrow \mathrm{C}^{\alpha} \mathrm{H} \leftrightarrow \mathrm{C}^{\beta} \mathrm{H}$ (2.3-2.6 8) connectivity. The remaining doublet resonance has been assigned to the Leu $\mathrm{NH}$. These assignments were made in $\mathrm{CDCl}_{3}$ solution. The corresponding assignments in $\left(\mathrm{CD}_{3}\right)_{2} \mathrm{SO}$ were based on solvent titration experiments, in which spectra were recorded in $\mathrm{CDCl}_{3}-\left(\mathrm{CD}_{3}\right)_{2} \mathrm{SO}$ mixtures. In these peptides, NH resonances were labeled as $S$, (singlets), $D_{n}$ (doublets), and $T_{n}$ (triplets), where the subscript " $n$ " refers to the order of appearance from low field in $\mathrm{CDCl}_{3}$. Although the Aib $\mathrm{NH}$ resonances were not assigned to individual residues, 'H-nmr results allowed deductions about molecular conformation. The chemical shifts of the various $\mathrm{NH}$ resonances in peptides $\mathrm{E}_{1-5}, \mathrm{E}_{6-10}, \mathrm{E}_{1-6}$, $\mathrm{E}_{1-7}, \mathrm{E}_{\mathbf{1 - 8}}, \mathrm{E}_{\mathbf{1 . 9}}$, and $\mathrm{E}_{1-10}$ are summarized in Tables II-V.

Solvent accessibility of NH groups was probed using temperature dependence of chemical shifts in DMSO, paramagnetic radical-induced broadening in $\mathrm{CDCl}_{3}$, and solvent perturbation experiments in $\mathrm{CDCl}_{3} /\left(\mathrm{CD}_{3}\right)_{2} \mathrm{SO}$ mix$\mathrm{t} \mathrm{u} \mathrm{r}$ e $\sim$.Therestlts of representative experiments for the decapeptide $\mathrm{E}_{1-10}$ are summarized in Figs. 5 and 6. The $d \boldsymbol{\delta} / d T$ values for the various peptides studied are listed in Tables II-V. In all cases strongly solvent-shielded NH groups are characterized by $d \delta / d T$ values $\leq \mathbf{0 . 0 0 3} \mathrm{ppm} / \mathrm{K}, \Delta \delta\left(\boldsymbol{\delta}_{\left(\mathrm{CD}_{3}\right)_{2} \text { so }}-\right.$ $\delta_{\mathrm{CDCl}_{3}}$ ) values $<0.5 \mathrm{ppm}$, and relatively little broadening in the presence of the paramagnetic radical TEMPO. In all the peptides the first two amino terminal residues are invariably characterized as fully exposed to the solvent by these criteria. For the amino terminal fragments $\mathrm{E}_{1-5}$ to $\mathrm{E}_{1-10}$ the two exposed NH resonances can be assigned to Phe(1) and $\mathrm{Aib}(2) \mathrm{NH}$, while for 
TABLE II

'H-NMR Parameters'

\begin{tabular}{|c|c|c|c|c|c|c|c|}
\hline \multicolumn{4}{|c|}{ Boc-Phe-Aib-Aib-Aib-Val-OMe $\left(E_{1-5}\right)$} & \multicolumn{4}{|c|}{ Boc-Gly-Leu-Aib-Aib-Hyp-OMe $\left(\mathrm{E}_{6-10}\right)$} \\
\hline $\begin{array}{l}\text { NH } \\
\text { Resonances }^{b}\end{array}$ & $\begin{array}{c}\delta(\mathrm{ppm}) \\
\mathrm{CDCl}_{3}\end{array}$ & $\begin{array}{c}\delta(\mathrm{ppm}) \\
\left(\mathrm{CD}_{3}\right)_{2} \mathrm{SO}\end{array}$ & $\begin{array}{c}d \delta / d T \\
(\mathrm{ppm} / \mathrm{K}) \\
\left(\mathrm{CD}_{3}\right)_{2} \mathrm{SO}\end{array}$ & $\begin{array}{l}\text { NH } \\
\text { Resonances }^{b}\end{array}$ & $\begin{array}{c}\delta(\mathrm{ppm}) \\
\mathrm{CDCl},\end{array}$ & $\begin{array}{c}\delta(\mathrm{ppm}) \\
\left(\mathrm{CD}_{3}\right)_{2} \mathrm{SO}\end{array}$ & $\begin{array}{c}d \delta / d T \\
(\mathrm{ppm} / \mathrm{K}) \\
\left(\mathrm{CD}_{3}\right)_{2} \mathrm{SO}\end{array}$ \\
\hline $\mathrm{D}_{1}(\text { Val NH})^{6}$ & 7.48 & 7.46 & 0.0024 & $\mathrm{~S}_{1}[\mathrm{Aib}(4) \mathrm{NH}]$ & 7.29 & 7.33 & 0.0016 \\
\hline $\mathrm{S}_{2}[\mathrm{Aib}(4) \mathrm{NH}]$ & 7.31 & 7.44 & 0.0026 & $\mathrm{D}_{2}($ Leu NH $)$ & 7.20 & 8.01 & 0.0050 \\
\hline $\mathrm{S},[\mathrm{Aib}(3) \mathrm{NH}]$ & 7.16 & 7.43 & 0.0034 & $\mathrm{~S}[\mathrm{Aib}(3) \mathrm{NH}]$ & 7.09 & 8.22 & 0.0062 \\
\hline $\mathrm{S}_{4}[\mathrm{Aib}(2) \mathrm{NH}]$ & 6.32 & 8.43 & 0.0042 & $\mathrm{~T}_{4}(\mathrm{Gly} \mathrm{NH})$ & 5.72 & 6.94 & 0.0048 \\
\hline$D_{5}\left(\right.$ Phe NH) ${ }^{6}$ & 5.10 & 7.11 & 0.0082 & & & & \\
\hline
\end{tabular}

a Peptide concentration: - $10 \mathrm{~m} M$.

${ }^{b} \mathrm{Aib}$ NH resonances have been assigned tentatively.

${ }^{c} J_{\mathrm{HNC}^{\alpha} \mathrm{H}}(\mathrm{Hz})$ values are $\mathrm{E}_{1-5}$, Val NH, 8.0 $\left(\mathrm{CDCl}_{3}\right), 6.5\left[\left(\mathrm{CD}_{3}\right)_{2} \mathrm{SO}\right)$; Phe NH, $4.4(\mathrm{CDCl}),, 5.1\left[\left(\mathrm{CD}_{3}\right)_{2} \mathrm{SO}\right] . \mathrm{E}_{6-10}, \mathrm{Leu} \mathrm{NH,} \mathrm{5.1}(\mathrm{CDCl}),, 5.8\left[(\mathrm{CD})_{2} \mathrm{SO}\right]$. 
TABLE III

'H-NMR Parameters'

\begin{tabular}{|c|c|c|c|c|c|c|c|}
\hline \multicolumn{4}{|c|}{ Boc-Phe-Aib-Aib-Aib-Val-Gly-OMe $\left(\mathrm{E}_{1-6}\right)$} & \multicolumn{4}{|c|}{ Boc-Phe-Aib-Aib-Aib-Val-Gly-Leu-OMe( $\left.\mathbf{E}_{1-7}\right)$} \\
\hline $\begin{array}{l}\mathrm{NH} \\
\text { Resonances }^{\mathrm{b}}\end{array}$ & $\begin{array}{c}\delta(\mathbf{p p m}) \\
\text { CDCI }\end{array}$ & $\begin{array}{c}\delta(\mathrm{ppm}) \\
\left(\mathrm{CD}_{3}\right)_{2} \mathrm{SO}\end{array}$ & $\begin{array}{c}d \delta / d T \\
(\mathrm{ppm} / \mathrm{K}) \\
\left(\mathrm{CD}_{3}\right)_{2} \mathrm{SO}\end{array}$ & $\begin{array}{l}\text { NH } \\
\text { Resonances }^{b}\end{array}$ & $\begin{array}{c}\delta(\mathrm{ppm}) \\
\mathrm{CDCl}_{3}\end{array}$ & $\begin{array}{c}\delta(\mathrm{ppm}) \\
\left(\mathrm{CD}_{3}\right)_{2} \mathrm{SO}\end{array}$ & $\begin{array}{c}d \delta / d T \\
(\mathrm{ppm} / \mathrm{K}) \\
\left(\mathrm{CD}_{3}\right)_{2} \mathrm{SO}\end{array}$ \\
\hline $\mathrm{T}_{1}(\mathrm{Gly} \mathrm{NH})$ & 7.85 & 7.87 & 0.0032 & $\mathbf{T}_{1}($ Gly NH) & 7.95 & 7.79 & 0.0016 \\
\hline $\mathrm{S}_{2}(\mathrm{Aib} \mathrm{NH})$ & 7.62 & 7.69 & 0.0035 & $\mathrm{~S}_{2}[\operatorname{Aib}(3) \mathrm{NH}]$ & 7.68 & 7.81 & 0.0042 \\
\hline $\mathrm{D}_{3}(\mathrm{Val} \mathrm{NH})^{\mathrm{C}}$ & 7.35 & 7.33 & 0.0020 & $\mathrm{~S} 3[\mathrm{Aib}(4) \mathrm{NH}]$ & 7.47 & 7.70 & 0.0028 \\
\hline $\mathrm{S}_{4}(\mathrm{Aib} \mathrm{NH})$ & 7.30 & 7.65 & 0.0030 & $\mathrm{D}_{4}(\mathrm{Val} \mathrm{NH})^{\mathrm{c}}$ & 7.32 & 7.69 & 0.0035 \\
\hline $\mathrm{S}_{5}[\mathrm{Aib}(2) \mathrm{NH}]$ & 6.46 & 8.41 & 0.0058 & $\mathrm{D}_{5}(\operatorname{Leu~NH})^{\mathrm{C}}$ & 7.09 & 7.26 & 0.0011 \\
\hline \multirow[t]{2}{*}{$\mathrm{D}_{6}(\mathrm{PheNH})^{\mathrm{c}}$} & 5.05 & 7.06 & 0.0068 & $\mathrm{~S}_{6}[\mathrm{Aib}(2) \mathrm{NH}]$ & 6.52 & 8.48 & 0.0064 \\
\hline & & & & $\mathrm{D}_{7}(\mathrm{PheNH})^{\mathrm{c}}$ & 5.10 & 7.06 & 0.0066 \\
\hline
\end{tabular}

a Peptide concentration: - $10 \mathrm{mM}$.

${ }^{b}$ Assignments of $\mathrm{Aib} \mathrm{NH}$ resonances are tentative.

${ }^{c} J_{\mathrm{HNC}^{\alpha} \mathrm{H}}$ values $(\mathrm{Hz})$ are $\mathbf{E}_{1.6}$, Val $\mathrm{NH}, 7.7\left(\mathrm{CDCl}_{3}\right), 6.5\left[\left(\mathrm{CD}_{3}\right)_{2} \mathrm{SO}\right] ;$ Phe NH, 7.3[( $\left.\left.\left(\mathrm{CD}_{3}\right)_{2} \mathrm{SO}\right] . \mathrm{E}_{1-7}, \mathrm{Val} \mathrm{NH}, 7.3(\mathrm{CDCI}), 7.3\left[(\mathrm{CD})_{2}\right)_{2} \mathrm{SO}\right] ; \mathrm{Leu} \mathrm{NH} 8.7$ (CDCI,), 8.5[( $\left.\left(\mathrm{CD}_{3}\right)_{2} \mathrm{SO}\right] ;$ Phe NH 7.0[( $\left.\left(\mathrm{CD}_{3}\right)_{2} \mathrm{SO}\right]$. 
TABLE IV

'H-NMR Parameters

\begin{tabular}{|c|c|c|c|c|c|c|c|}
\hline \multicolumn{4}{|c|}{ Boc-Phe-Aib-Aib-Aib-Val-Gly-Ieu-Aib-OM $\left(\mathrm{E}_{1-8}\right)^{a}$} & \multicolumn{4}{|c|}{ Boc-Phe-Aib-Aib-Aib-Val-Gly-LeuAib-Aib-OMe $\left(\mathrm{E}_{\mathbf{1 - 9}}\right)^{\mathbf{b}}$} \\
\hline $\begin{array}{l}\mathrm{NH} \\
\text { Resonances' } \\
\end{array}$ & $\begin{array}{c}\delta(\mathbf{p p m}) \\
\mathrm{CDCl}_{3}\end{array}$ & $\begin{array}{c}\delta(\mathrm{ppm}) \\
\left(\mathrm{CD}_{3}\right)_{2} \mathrm{SO}\end{array}$ & $\begin{array}{c}d \delta / d T \\
(\mathrm{ppm} / \mathrm{K}) \\
\left(\mathrm{CD}_{3}\right)_{2} \mathrm{SO}\end{array}$ & $\begin{array}{l}\mathrm{NH} \\
\text { Resonances }^{\mathrm{c}}\end{array}$ & $\begin{array}{c}\delta(\mathrm{ppm}) \\
\mathrm{CDCl}_{3}\end{array}$ & $\begin{array}{c}\delta(\mathrm{ppm}) \\
\left(\mathrm{CD}_{3}\right)_{2} \mathrm{SO}\end{array}$ & $\begin{array}{c}d \delta / d T \\
(\mathrm{ppm} / \mathrm{K}) \\
\left(\mathrm{CD}_{3}\right)_{2} \mathrm{SO} \\
\end{array}$ \\
\hline $\mathrm{T}_{1}(\mathrm{Gly} \mathrm{NH})$ & 8.06 & 7.80 & 0.0018 & $\mathrm{~T}_{1}$ (Gly NH) & 8.08 & 7.87 & 0.0020 \\
\hline $\mathrm{S}_{2}(\mathrm{Aib} \mathrm{NH})$ & 7.74 & 7.80 & 0.0030 & $\mathrm{~S},(\mathrm{Aib} N \mathrm{NH})$ & 7.79 & 7.84 & 0.0034 \\
\hline $\mathrm{D}_{3}(\mathrm{Val} \mathbf{N H})^{\mathrm{d}}$ & 7.56 & 7.53 & 0.0035 & $\mathrm{D}_{3}(\mathrm{Val} \mathbf{N H})^{\mathbf{d}}$ & 7.67 & 7.61 & 0.0035 \\
\hline $\mathrm{S}_{4}[\mathrm{Aib}(3) \mathrm{NH}]$ & 7.52 & 7.94 & 0.0066 & $\mathrm{~S}_{\mathbf{4}}[\mathrm{Aib}(3) \mathrm{NH}]$ & 7.56 & 7.85 & 0.0054 \\
\hline $\mathbf{S}_{5}(\mathrm{Aib} \mathrm{NH})$ & 7.40 & 7.70 & 0.0024 & $\mathrm{D}_{5}(\text { LeuNH })^{\mathrm{d}}$ & 7.32 & 7.42 & 0.0008 \\
\hline$D_{6}(\text { Leu NH })^{d}$ & 7.34 & 7.41 & 0.0014 & $\mathrm{~S}_{6}(\mathrm{Aib} \mathrm{NH})$ & 7.16 & 7.72 & 0.0022 \\
\hline $\mathrm{S}_{7}[\mathrm{Aib}(2) \mathrm{NH}]$ & 6.53 & 8.47 & 0.0064 & $\mathrm{~S},(\mathrm{Aib} N \mathrm{~N})$ & 7.07 & 7.23 & 0.0020 \\
\hline \multirow[t]{2}{*}{$\mathrm{D}_{\mathrm{g}}(\mathrm{PheNH})^{\mathbf{d}}$} & 5.11 & 7.05 & 0.0064 & $\mathrm{~S}_{8}[\mathrm{Aib}(2) \mathrm{NH}]$ & 6.56 & 8.49 & 0.0062 \\
\hline & & & & $\mathrm{D}_{\mathbf{9}}(\mathrm{Phe} \mathbf{N H})^{\mathrm{d}}$ & 5.17 & 7.05 & 0.0064 \\
\hline
\end{tabular}

${ }^{8}$ Peptide concentration: $-8 \mathrm{mM}$

${ }^{b}$ Peptide concentration: - $5 \mathrm{~m} M$.

All the Aib residues could not be assigned.

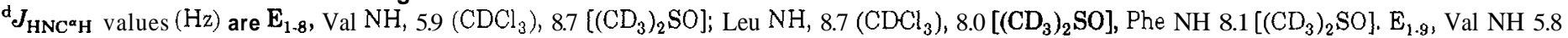
$\left(\mathrm{CDCl}_{3}\right), 6.3\left[\left(\mathrm{CD}_{3}\right)_{2} \mathrm{SO}\right]$; Leu NH $\left.5.1\left(\mathrm{CDCl}_{3}\right), 7.3\left[\mathrm{CD}_{3}\right)_{2} \mathrm{SO}\right] ;$ Phe NH $7.3\left[\left(\mathrm{CD}_{3}\right)_{2} \mathrm{SO}\right.$. 
TABLE V

${ }^{1}$ H-NMR Parameters ${ }^{a}$ for Boc-Phe-Aib-Aib-Aib-Val-Gly-Leu-Aib-Aib-Hyp-OMe (E $\left.E_{1-10}\right)$

\begin{tabular}{|c|c|c|c|}
\hline NH Resonancesb & $\begin{array}{c}\delta(\mathrm{ppm}) \\
\mathrm{CDCl}\end{array}$ & $\begin{array}{c}\delta(\mathrm{ppm}) \\
\left(\mathrm{CD}_{3}\right)_{2} \mathrm{SO}\end{array}$ & $\begin{array}{c}d \delta / d T \\
(\mathrm{ppm} / \mathrm{K})\end{array}$ \\
\hline $\mathrm{T}_{1}($ Gly NH) & 8.08 & 7.90 & 0.0010 \\
\hline $\mathrm{S}_{2}(\mathrm{Aib} \mathrm{NH})$ & 7.91 & 7.83 & 0.0034 \\
\hline $\mathrm{D}_{3}(\text { Val NH })^{\mathrm{c}}$ & 7.70 & 7.56 & 0.0032 \\
\hline $\mathrm{S}_{4}[\mathrm{Aib}(3) \mathrm{NH}]$ & 7.69 & 7.78 & 0.0048 \\
\hline $\mathrm{D}_{5}(\text { Leu NH})^{6}$ & 7.32 & 7.47 & 0.0014 \\
\hline $\mathrm{S}_{6}(\mathrm{Aib} \mathrm{NH})$ & 7.30 & 7.74 & 0.0022 \\
\hline $\mathrm{S}_{?}(\mathrm{Aib} \mathrm{NH})$ & 7.19 & 7.24 & 0.0018 \\
\hline $\mathrm{S}_{8}[\mathrm{Aib}(2) \mathrm{NH}]$ & 7.13 & 8.56 & 0.0062 \\
\hline $\mathrm{D}_{9}$ (Phe NH)" & 5.82 & 7.05 & 0.0050 \\
\hline
\end{tabular}

a Peptide concentration: - $5 \mathrm{mM}$.

${ }^{b}$ Aib resonances, wherever mentioned, are tentatively assigned.

${ }^{c} J_{\mathrm{HNC}^{\alpha} \mathrm{H}}$ values $(\mathrm{Hz})$ are Val NH, $6.3(\mathrm{CDCI}), 5.8\left[\left(\mathrm{CD}_{3}\right)_{2} \mathrm{SO}\right]$; Leu NH $7.7\left[\left(\mathrm{CD}_{3}\right)_{2} \mathrm{SO}\right]$; Phe $\mathrm{NH}, 8.0\left[\left(\mathrm{CD}_{3}\right)_{2} \mathrm{SO}\right]$.
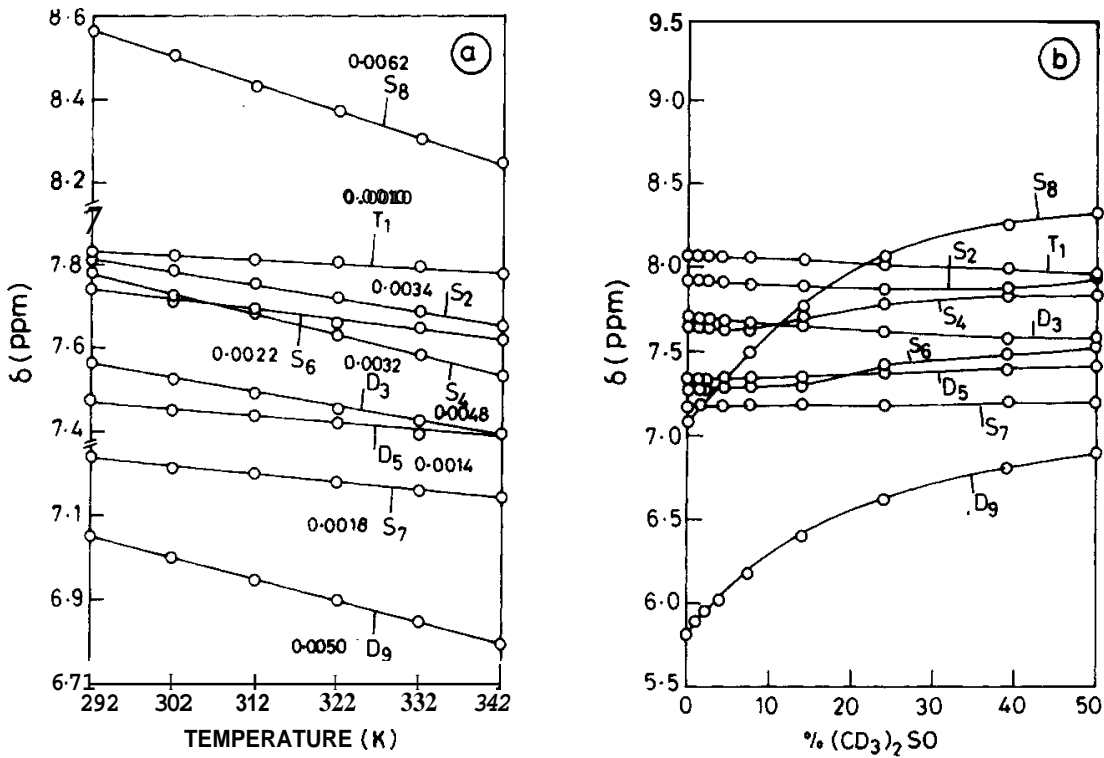

Fig. 5. (a) Temperature dependence of $\mathrm{NH}$ proton chemical shifts of the peptide Boc-Phe(Aib) $)_{3}$-Val-Gly-Leu-Aib-Aib-Hyp-OMe $\left(\mathrm{E}_{1-10}\right)$ in $\left(\mathrm{CD}_{3}\right)_{2} \mathrm{SO}$. (b) Solvent dependence of NH proton chemical shifts of the peptide $\mathrm{E}_{1-10}$ in $\mathrm{CDCl}_{3} \cdot\left(\mathrm{CD}_{3}\right)_{2} \mathrm{SO}$ mixtures. $\mathrm{S}_{\mathrm{n}}, \mathrm{D}_{\mathrm{n}}$, and $T_{\mathrm{n}}$ refer to singlet, doublet and triplet resonances. The subscript " $n$ " refers to the order of appearance from low field in $\mathrm{CDCl}, . d \delta / d T$ values for the $\mathrm{NH}$ protons are indicated against the traces in (a).

$\mathbf{E}_{6-10}$, the Gly(1) and Leu(2) NH groups are solvent exposed. From the assignments in Tables II-V, it can be seen that in the peptides $\mathrm{E}_{1-5}$ and $\mathrm{E}_{1-6}$ one of the Aib NH groups has an intermediate $d \delta / d T$ value of 0.0035 $\mathrm{ppm} / \mathrm{K}$, although the A8 values are small. In $\mathbf{E}_{1-7}$ one Aib $\mathrm{NH}$ [tentatively assigned to $\mathrm{Aib}(3) \mathrm{NH}$ ] and $\mathrm{Val}(5) \mathrm{NH}$ have moderate $\boldsymbol{d} \boldsymbol{\delta} / \boldsymbol{d T}$ values. In $\mathrm{E}_{1-8}$ and $\mathrm{E}_{1.9}$ one additional Aib $\mathrm{NH}$ assigned to $\mathrm{Aib}(3) \mathrm{NH}$ is clearly solvent exposed, as evidenced by its high $d \delta / d T$ value. Furthermore, the $\operatorname{Val}(5) \mathrm{NH}$ 


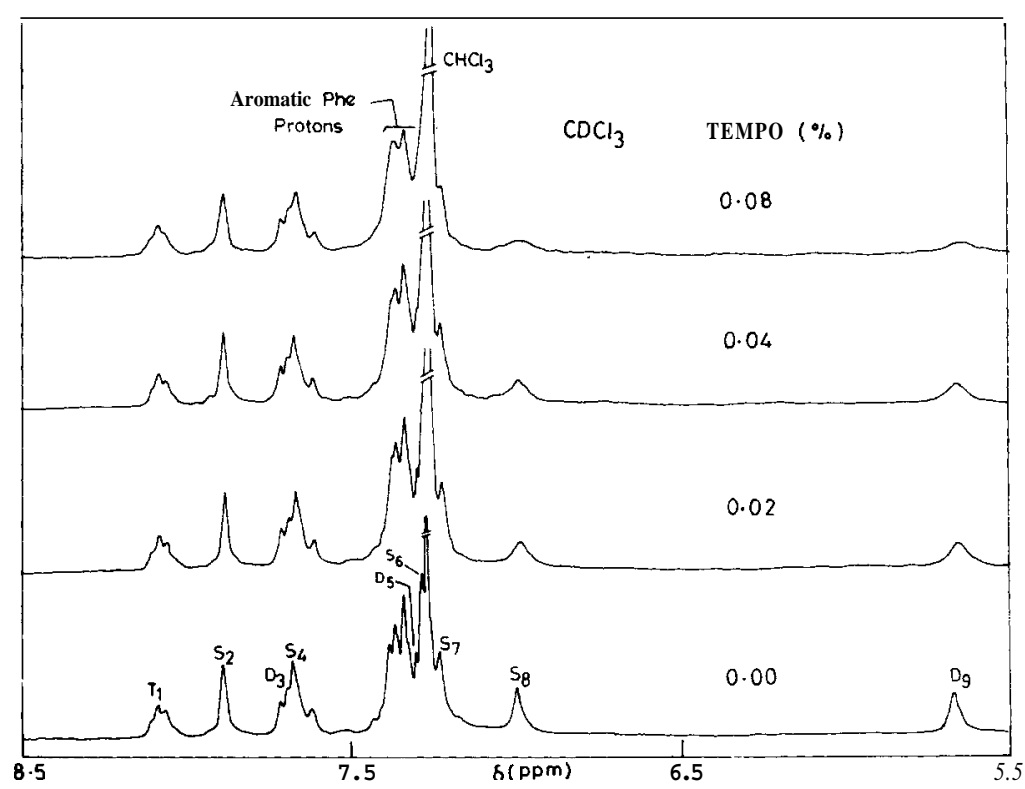

Fig. 6. Partial $270-\mathrm{MHz}{ }^{1} \mathrm{H}-\mathrm{nmr}$ spectra of $\mathrm{NH}$ resonances in $\mathrm{CDCl}$, as a function of TEMPO concentration. The individual resonances are indicated as in Fig. 5.

in both these peptides is only moderately shielded. In $\mathrm{E}_{1-10}$ one Aib $\mathrm{NH}$ appears appreciably solvent exposed in addition to the two amino terminal $\mathrm{NH}$ groups. The number of strongly (partially) shielded $\mathrm{NH}$ groups in $\left(\mathrm{CD}_{3}\right)_{2} \mathrm{SO}$ in the various peptides are $\mathrm{E}_{1-5} 2(1), \mathrm{E}_{6 \cdot 10} 1, \mathrm{E}_{1-6} 3(1), \mathrm{E}_{1-7} 3(1), \mathrm{E}_{1-8}$ $4(1)$ and $\mathrm{E}_{1-9} 4(2)$, and $\mathrm{E}_{1-10} 4(2)$. These estimates are based on the $d \delta / d T$ values.

In $\mathrm{CDCl}_{3}$, only two $\mathrm{NH}$ groups corresponding to residues 1 and 2 appear solvent exposed. These resonances show appreciable shifts on addition of strongly hydrogen bond accepting solvents like $\left(\mathrm{CD}_{3}\right)_{2} \mathrm{SO}$ up to a concentration of 20 volume percent in $\mathrm{CDCl}$, solutions. Furthermore, these resonances also broaden considerably relative to the remaining $\mathrm{NH}$ resonances on addition of the paramagnetic radical. The $\mathrm{nmr}$ results thus suggest small differences in the conformations of the peptides in $\mathrm{CDCl}$, and $\left(\mathrm{CD}_{3}\right)_{2} \mathrm{SO}$, with a greater number of solvent-shielded NH groups in the former. In $\mathrm{nmr}$ studies of similar acyclic peptides, solvent-shielded NH resonances have almost invariably been assigned to intramolecularly hydrogen-bonded $\mathrm{NH}$ groups. $^{22,26-29}$

The $J_{\mathrm{HNC}^{\alpha} \mathrm{H}}$ values for the L-amino acid residues in the various peptides are listed in footnotes to Tables II-V. The Phe $(1) \mathrm{NH}$ has a low value $(<5 \mathrm{~Hz})$ in $\mathrm{CDCl}$, in all the peptides and is in fact, a broad unresolved doublet resonance in sequences longer than $\mathbf{E}_{1-5.5}$. The $J_{\mathrm{HNC}^{\alpha} \mathbf{H}}$ values in $\left(\mathrm{CD}_{3}\right)_{2} \mathrm{SO}$ are somewhat larger for Phe(1) NH. The $J_{\mathrm{HNC}^{\alpha} \mathrm{H}}$ value in $\mathrm{CDCl}$, for Val NH is $<8 \mathrm{~Hz}$ in all peptides except $\mathbf{E}_{1-5}$, where this is the C-terminal residue. The changes when going to $\left(\mathrm{CD}_{3}\right)_{2} \mathrm{SO}$ are very small except in the case of $\mathrm{E}_{1-8}$. For Leu $\mathrm{NH}$, large $J_{\mathrm{HNC}^{\alpha} \mathrm{H}}$ values $(>8 \mathrm{~Hz})$ are observed for $\mathrm{E}_{1-7}$ and $\mathrm{E}_{1-8}$. Helical conformations will generally be characterized by low $J_{\mathrm{HNC}^{a} \mathrm{H}}$ values $(<5 \mathrm{~Hz})$ and more extended structures by large values $(>8 \mathrm{~Hz}){ }^{30}$ The limited number 

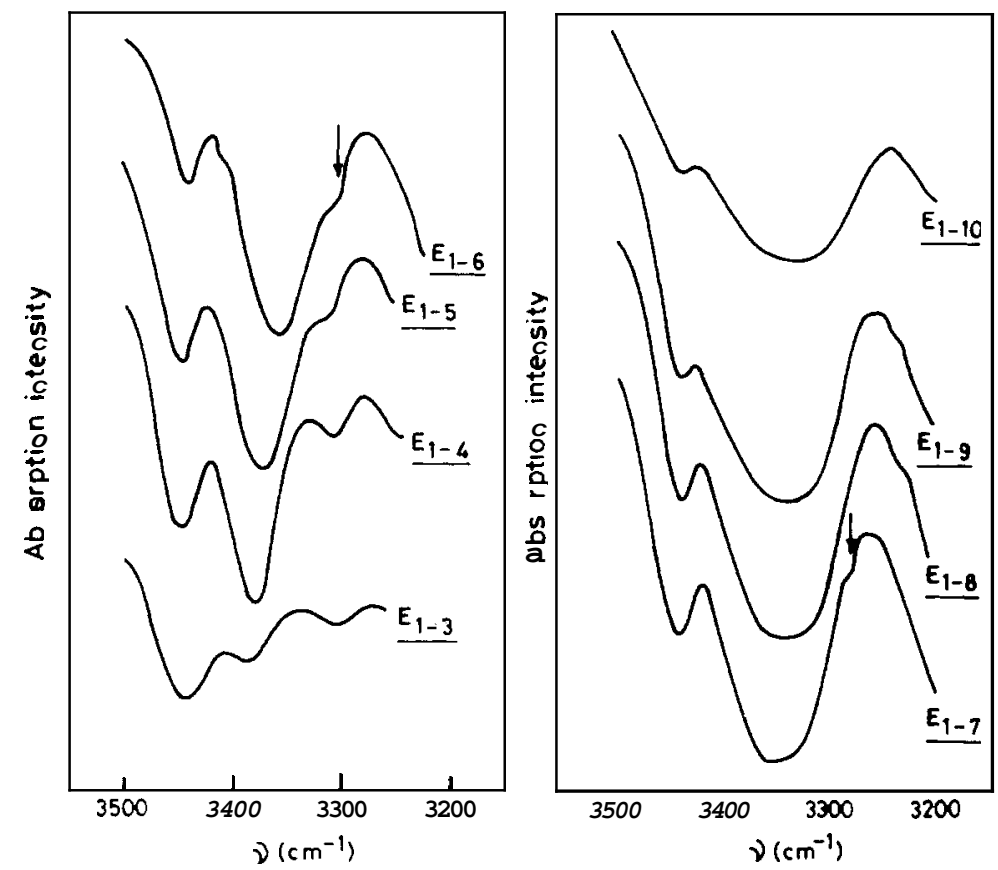

Fig. 7. Infrared spectra (NH-stretching bands) of synthetic emerimicin fragments in $\mathrm{CHCl}_{3}$ solutions at $2 \times 10^{-4} \mathrm{M}$. The arrows indicate the position of the solvent absorption band.

of non-Aib residues in these sequences, and their positioning near or at the chain termini in several peptide fragments, precludes a more detailed analysis of the conformations based on $J_{\mathrm{HNC}^{\alpha} \mathrm{H}}$ values. Indeed, as noted later, the possibility of interconversions between helical conformations of opposite handedness can lead to dynamic averaging of $\mathbf{J}$ values. The $\mathrm{nmr}$ data in $\mathrm{CDCl}_{3}$ may also be influenced by peptide association. ${ }^{31-33}$ However, as noted earlier for helical Aib-containing sequences, aggregation does not perturb intramolecular hydrogen-bonding patterns but occurs through the mediation of solvent-exposed $\mathrm{NH}$ groups. ${ }^{32,33}$

Infrared studies can be used to directly estimate the extent of intramolecular hydrogen bonding. ${ }^{34}$ The $\mathrm{NH}$ stretching regions of the ir spectra of the $\mathrm{N}$-terminal fragments of emerimicin III and IV with increasing chain length from tripeptide to decapeptide in chloroform solution, at the concentration $2 \times 10^{-4} \boldsymbol{M}$, are shown in Fig. 7. At this concentration it is generally assumed that only intramolecular hydrogen bonds are predominant. ${ }^{34-37}$ Under identical conditions all $\mathrm{N}$-terminal fragments from tripeptide to decapeptideexhibit two NH-stretching bands at 3440-3445 $\mathrm{cm}^{-1}$ and at $3330-3380 \mathrm{~cm}^{-1}$ (Fig. 7) characteristic of free $\left[\nu_{\mathrm{NH}}(\mathrm{f})\right]$ and hydrogen-bonded $\left[\nu_{\mathrm{NH}}(\mathrm{hb})\right]$ stretching frequencies, respectively. The lower frequency band at $3330-3380 \mathrm{~cm}^{-1}$ observed in these peptides at the concentration $2 \times 10^{-4} M$ may be assigned to intramolecularly hydrogen-bonded $\mathrm{NH}$ groups.

A plot of the ratio of the intensities of the bands $\left[\nu_{\mathrm{NH}}(\mathrm{hb}) / \nu_{\mathrm{NH}}(\mathrm{f})\right]$ as a function of chain length increases regularly from tripeptide to nonapeptide (Fig. 8). This suggests that an increase in the chain length accompanied by an increase in the number of $\mathrm{NH}$ groups leads to the folding of the peptide 


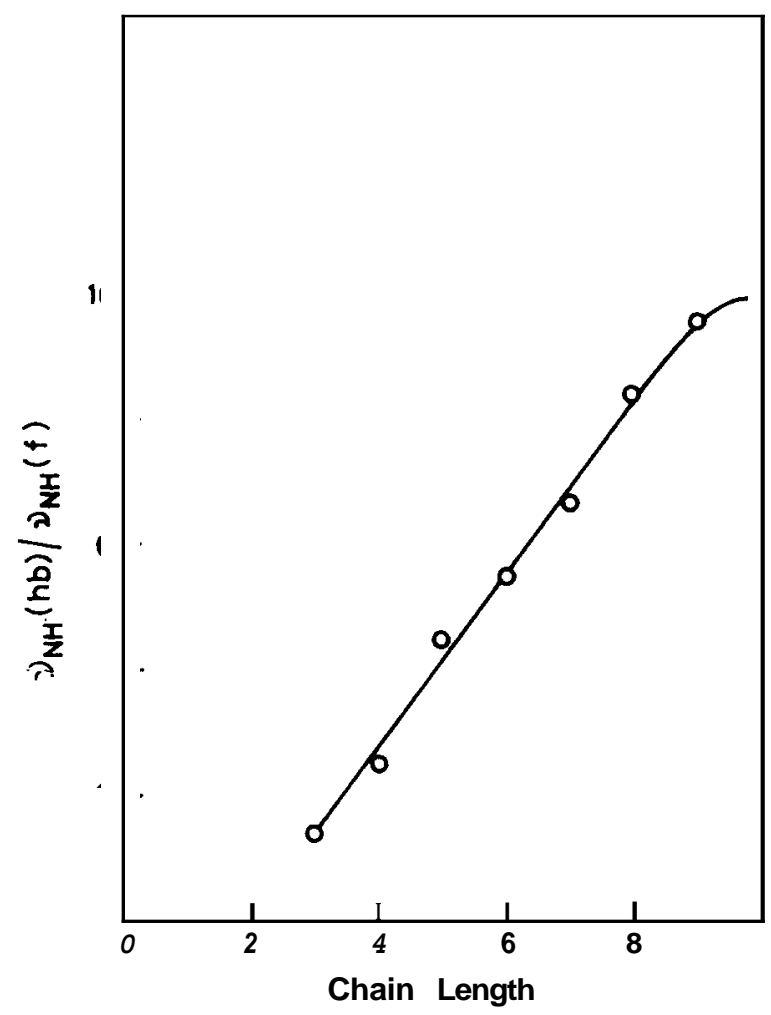

Fig. 8. A plot of the ratio of the intensities of the NH-stretching bands $\left[\nu_{N H}(h b) / \nu_{N H}(f)\right]$ as a function of chain length for the N-terminal fragments of emerimicin III and IV. $\nu_{\mathrm{NH}}(\mathrm{f})$, $3440-3445 \mathrm{~cm}^{-1}$ and $\nu_{\mathrm{NH}}(\mathrm{hb}), 3330-3380 \mathrm{~cm}^{-1}$.

backbone, with an increase in the number of intramolecularlyhydrogen-bonded NH groups. Similar results have been obtained for homooligopeptides of $\mathrm{Aib}\left(\mathrm{Z}(\mathrm{Aib})_{n} \mathrm{OtBu} \boldsymbol{n}=\mathbf{3 , 4 , 5}\right)^{\mathbf{3 6}}$ and amino terminal alamethicin fragments. ${ }^{35}$ There is not much difference in the ratio $\left[\nu_{N H}(\mathrm{hb}) / \nu_{\mathrm{NH}}(\mathrm{f})\right]$ for the nonapeptide $\mathbf{E}_{1-9}$ and the decapeptide $\mathbf{E}_{\mathbf{1 - 1 0}}$. This is reasonable, since both peptides may be expected to have the same number of hydrogen-bonded NH groups.

The intensity of the hydrogen-bonded NH-stretching band can be used to quantitatively estimate the number of intramolecularly hydrogen-bonded $\mathrm{NH}$ groups. ${ }^{1} \mathrm{H}-\mathrm{nmr}$ studies of the tetrapeptide $\mathbf{E}_{1-4}$ show the presence of two intramolecular hydrogen bonds, as reported earlier. ${ }^{15}$ The intensity of the $\nu_{\mathrm{NH}}(\mathrm{hb})$ band for this peptide is taken to be equivalent to two hydrogen bonds. On this basis the number of intramolecularly hydrogen-bonded $\mathrm{NH}$ groups as determined from the $\nu_{\mathrm{NH}}(\mathrm{hb})$ band intensities of these peptides are $E_{1-3}$ one, $E_{1-5}$ three, $E_{1-6}$ four, $E_{1-7}$ five, $E_{1-8}$ six, $E_{1-9}$ seven, and $E_{1-10}$ seven. Similar studies have also been reported for alamethicin fragments ${ }^{34,35}$ and model peptides. ${ }^{36}$

\section{Backbone Conformations}

The only peptide that shows a single solvent-shielded $\mathrm{NH}$ group is the central pentapeptide $\mathrm{E}_{6 \cdot 10}$. Here the lone shielded $\mathrm{NH}$ group can be assigned 
a

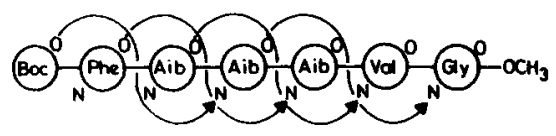

b

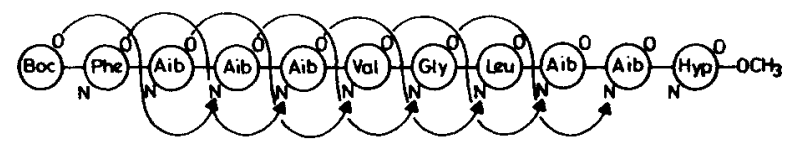

C

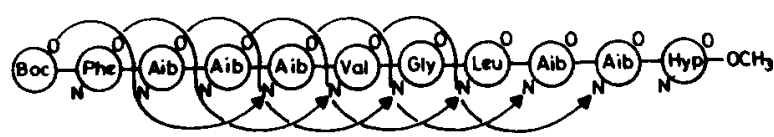

Fig. 9. Schematic hydrogen-bonding schemes proposed for peptides $E_{1-6}(a)$ and $E_{1-10}(b, c)$, consistent with the spectral data. (b) $3_{10}$-helical conformation and (c) a-helical conformation.

to Aib(4) NH stabilizing a Leu-Aib $\beta$-turn conformation, with an intramolecular $\mathbf{4} \rightarrow 1$ hydrogen bond between $\mathrm{Aib}(4) \mathrm{NH}$ and Gly(1) CO. This conformation may be favored because of the tendency of X-Aib sequence to adopt p-turn structures. ${ }^{4,7}$ For the remaining amino terminal fragments, the nmr and ir studies in chloroform indicate a progressive increase in the number of intramolecular hydrogen bonds when going from $\mathrm{E}_{1-4}$ to $\mathrm{E}_{1-9}$. As expected, $\mathbf{E}_{1-10}$ and $\mathbf{E}_{1-9}$ appear to possess the same number of intramolecularhydrogen bonds since the C-terminal residue in the former is Hyp, which does not possess an NH group. These results are consistent with the extension of a $3_{10}$-helical structure, stabilized by successive $4 \rightarrow 1$ intramolecular hydrogen bonds. Typical hydrogen-bonding patterns compatible with the spectral data in chloroform are shown in Fig. 9. The observed helical folding is fully consistent with the tendency of Aib-rich sequences to adopt $3_{10^{-}}$or a-helical conformations. ${ }^{4-7,38-42}$

A particular point of interest in the sequence of emerimicin is the presence of an L-amino acid (L-Phe) as the N-terminal residue. This raises the possibility that the amino terminal $\beta$-turn with $\mathrm{Phe}(1)$ and $\mathrm{Aib}(2)$ as the corner residues may in fact be either type II $\left(\phi_{\mathrm{Phe}}--60^{\circ}, \psi_{\mathrm{Phe}} \sim+120^{\circ}, \phi_{\mathrm{Aib}}-\right.$ $\left.+70^{\circ} \psi_{\text {Aib }} \sim 20^{\circ}\right)$ or type III $\left(\phi_{\text {Phe }}=\phi_{\text {Aib }}=-60^{\circ} ; \psi_{\text {Phe }}=\psi_{\text {Aib }}=-30^{\circ}\right) .^{43}$ In the former case the successive $\beta$-turns must belong to the type III category, ${ }^{7,44}$ which would imply a left-handed helical folding of the segment following residue 2 . In the latter case, a succession of type III $\beta$-turns would generate a $3_{10}$-helix. A recent study of antiamoebin, a fungal peptide produced by Emericellopsis poonensis Thirum., Emericellopsis synnematicola Mathur and Thirum, and Cephalosporium pimprina Thirum, which also possesses L-Phe-Aib as the first two residues, suggest a Type II p-turn conformation for this segment. ${ }^{44}$ Such conformations can be readily recognized by the presence of an interresidue NOE between the Phe(1) $\mathrm{C}^{\alpha} \mathrm{H}$ and $\mathrm{Aib}(2) \mathrm{NH}$ protons. ${ }^{21,44}$ 


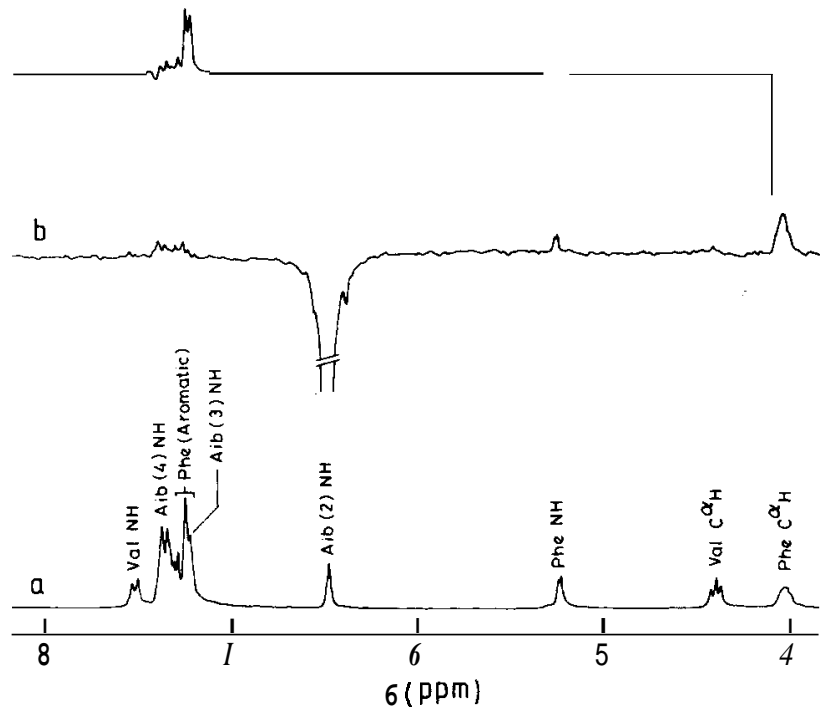

Fig. 10. (a) Partial 270-MHz ${ }^{1} \mathrm{H}-\mathrm{nmr}$ spectrum of $\mathrm{E}_{1-5}$ in $\mathrm{CDCl}_{3}$. (b, c) Difference NOE spectra (x 32) obtained by irradiation of $\mathrm{Aib}(2) \mathrm{NH}(\mathrm{b})$, and $\mathrm{Phe} \mathrm{C}^{\alpha} \mathrm{H}(\mathrm{c})$ resonances.

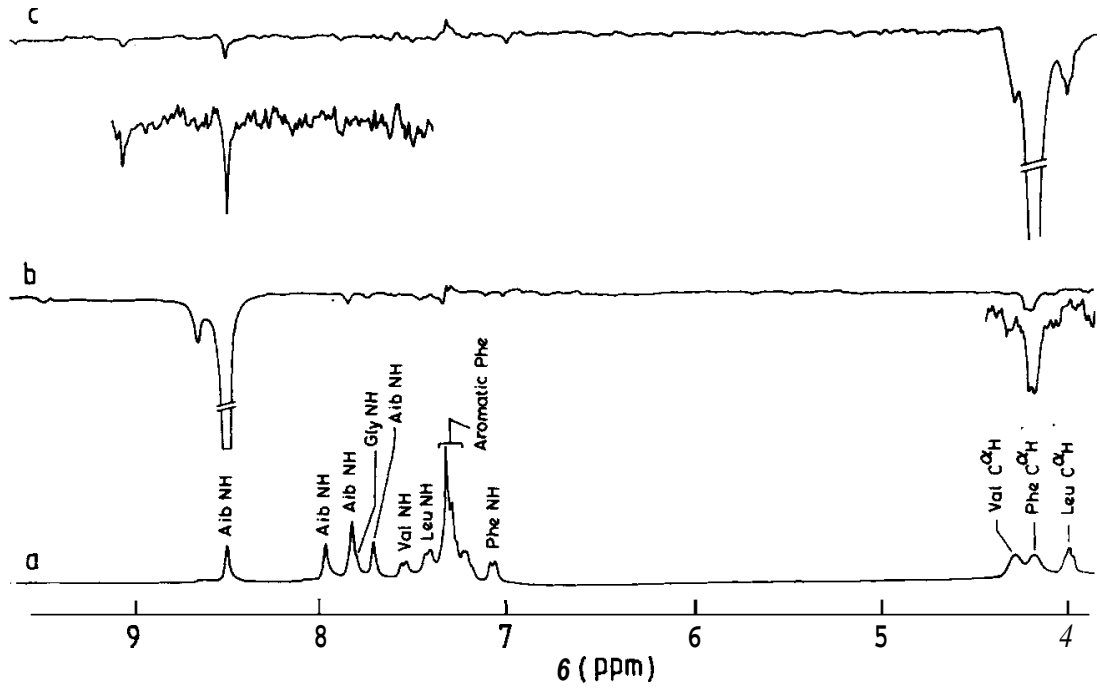

Fig. 11. (a) Partial $270-\mathrm{MHz}{ }^{1} \mathrm{H}-\mathrm{nmr}$ spectra of $\mathrm{E}_{1-8}$ in $\left(\mathrm{CD}_{3}\right)_{2} \mathrm{SO}$. (b,c) Difference NOE spectra ( $\times 16$ ) obtained by irradiation of $\mathrm{Aib} N H(b)$ and $\mathrm{Phe} \mathrm{C}^{\alpha} \mathrm{H}(\mathrm{c})$ resonances. The inset shows the Phe $\mathrm{C}^{\alpha} \mathrm{H} \leftrightarrow$ Aib NH NOE at higher magnification $(\times 64)$.

The results of representative difference NOE experiments on peptides $E_{1-5}$ and $\mathrm{E}_{1.8}$ are shown in Figs. 10 and 11. For $\mathrm{E}_{1-5}$ in $\mathrm{CDCl}_{3}$, irradiation of the Phe $\mathrm{C}^{\alpha} \mathrm{H}$ resonance results in clear positive NOEs on the Phe NH (intraresidue) and $\mathrm{Aib}(2) \mathrm{NH}$ (interresidue) protons. In addition, an NOE is also observed on the aromatic protons. Irradiation of the $\mathrm{Aib}(2) \mathrm{NH}$ results in a large NOE on the Phe $\mathrm{C}^{\alpha} \mathrm{H}$ proton and a smaller NOE on the Phe NH proton. The Phe $\mathrm{C}^{\alpha} \mathrm{H} \leftrightarrow \mathrm{Aib}(2) \mathrm{NH} \mathrm{NOE}$ is diagnostic of a $\psi_{\text {Phe }}$ value of - 120" 
TABLE VI

\begin{tabular}{|c|c|c|c|c|c|}
\hline \multirow[b]{3}{*}{ Emerimicin Fragments } & \multicolumn{3}{|c|}{$\begin{array}{l}\text { Number of Intramolecularly } \\
\text { Hydrogen-Bonded NH } \\
\text { Groups Determined from } \\
\text { Spectroscopic Studies }\end{array}$} & & \\
\hline & \multicolumn{2}{|c|}{${ }^{1} \mathrm{H}$ NMR } & \multirow{2}{*}{$\frac{\mathrm{IR}}{\mathrm{CDCl}_{3}}$} & \multicolumn{2}{|c|}{ Conformational Inference' } \\
\hline & $\mathrm{CDCl}_{3}$ & $\left(\mathrm{CD}_{3}\right)_{2} \mathrm{SO}$ & & $\mathrm{CDCl}_{3}$ & $\left(\mathrm{CD}_{3}\right)_{2} \mathrm{SO}$ \\
\hline Boc-Phe-Aib-Aib-Aib-OMeE ${ }_{1.4}$ & 2 & 2 & 2 & $\begin{array}{l}\text { Consecutive } \\
\beta \text {-turn (III-III, } \\
\text { III-III' or } \\
\text { II-III') }\end{array}$ & $\begin{array}{l}\text { Consecutive } \\
\text { p-turn (III-III, } \\
\text { III-III' or } \\
\text { II-III') }\end{array}$ \\
\hline Boc-Phe-Aib-Aib-Aib-Val-OMeE $E_{1-5}$ & 3 & 3 & 3 & $3_{10}$ & $3_{10}$ \\
\hline Boc-Phe-Aib-Aib-Aib-Val-Gly-OMtE $E_{1-6}$ & 4 & 4 & 4 & $3_{10}$ & $3_{10}$ \\
\hline Boc-Phe-Aib-Aib-Aib-Val-Gly-Leu-OMe $E_{1-7}$ & 5 & 4 & 5 & $3_{10}$ & $\begin{array}{l}\text { a or partially } \\
\text { opened } 3_{10}\end{array}$ \\
\hline Boc-Phe-Aib-Aib-Aib-Val-Gly-Leu-Aib-OMeE ${ }_{1-8}$ & 6 & 5 & 6 & $3_{10}$ & $\begin{array}{l}\text { a or partially } \\
\text { opened } 3_{10}\end{array}$ \\
\hline Boc-Phe-Aib-Aib-Aib-Val-Gly-Leu-Aib-Aib-OME $E_{1-9}$ & 7 & 6 & 7 & $3_{10}$ & $\begin{array}{l}\text { a or partially } \\
\text { opened } 3_{10}\end{array}$ \\
\hline Boc-Phe-Aib-Aib-Aib-Val-Gly-Leu-Aib-Aib-Hyp-OMe $\mathrm{E}_{1-10}$ & 7 & 6 & 7 & $3_{10}$ & $\begin{array}{l}\text { a or partially } \\
\text { opened } 3_{10}\end{array}$ \\
\hline
\end{tabular}

${ }^{a}$ If the nucleating Phe-Aib $\beta$-turn is type II, then a succeeding helix will be left handed, whereas a right-handed helix is obtained if the Phe-Aib segment occupies the corner positions of a type III $\beta$-turn. 
$\pm 30^{\circ},{ }^{45,46}$ supporting a type II $\beta$-turn conformation of this segment. The Phe $\mathrm{NH} \leftrightarrow \operatorname{Aib}(2) \mathrm{NH}$ NOE $\left(\mathrm{N}_{i+1} \mathrm{H} \leftrightarrow \mathrm{N}_{i+2} \mathrm{H}\right)$ is, however, not expected for the $i+1$ and $i+2$ residues of a type II $\beta$-turn. ${ }^{45}$ This NH-NH NOE is, in fact, characteristic of a helical conformation or a type III $\beta$-turn. ${ }^{45}$ The simultaneous observation of these two NOEs suggests that both conformational states are in fact populated in solution and that a rapid dynamic equilibrium exists between these structures. Indeed, the highest $d \delta / d T$ values observed for one of the Aib $\mathrm{NH}$ [tentatively assigned to $\mathrm{Aib}(3) \mathrm{NH}$ ] in DMSO in the case of the amino terminal emerimicin peptides is consistent with a degree of structural flexibility for the $\mathrm{N}$-terminal $\beta$-turns. Figure 11 shows the results of typical NOE experiments on the octapeptide $\mathrm{E}_{1.8}$ in DMSO. In this case the observed NOEs are negative, indicating that the molecular correlation time $\tau_{c}$ is long enough to make $\omega \tau_{c}>1 .^{47}$ The observed Phe $\mathrm{C}^{\alpha} \mathrm{H} \leftrightarrow \mathrm{Aib}(2) \mathrm{NH}$ NOE is again consistent with a type II $\beta$-turn conformation for the $\mathrm{N}$-terminal fragment. Interestingly, no NOE was detectable between Aib(2) NH and Phe $\mathrm{NH}$ protons. Table VI summarizes the results of the spectral studies on the emerimicin fragments and the conformational inferences drawn therefrom. The results of this study suggest the presence of an additional solvent-exposed $\mathrm{NH}$ groups in DMSO as compared to those for the longer peptides $\mathbf{E}_{\mathbf{1 - 7}}, \mathrm{E}_{\mathbf{1 - 8}}$, $\mathbf{E}_{\mathbf{1 - 9}}$, and $\mathbf{E}_{\mathbf{1 \cdot 1 0}}$. This $\mathrm{NH}$ group, which may be assigned to Aib(3) NH, may be exposed either due to partial unfolding of the N-terminal $\beta$-turn or by a population of $\alpha$-helical structures in which the first three $\mathrm{N}$-terminal $\mathrm{NH}$ groups are expected to be solvent exposed. A distinction between these two possibilities does not appear possible at this time. ${ }^{29}$

In considering left-handed $\mathbf{3}_{\mathbf{1 0}}$-helical structures for the longer fragments $E_{1.6}$ to $E_{1-10}$, it must be emphasized that such structures will necessitate positive $\phi, \psi$ values for L-Val and L-Leu residues. This region of conformational space is intrinsically less likely for L-residues. ${ }^{48} \mathrm{It}$ is noteworthy that the solvent exposure of the $\mathrm{Aib}(3) \mathrm{NH}$ in the longer peptides is appreciably greater, suggesting that right-handed helical conformations may be favored at the expense of destabilizing the $\mathrm{Phe}(1)$-Aib(2) $\beta$-turn. The simultaneous observation of the Phe(1) $\mathrm{C}^{\alpha} \mathrm{H} \leftrightarrow \operatorname{Aib}(2) \mathrm{NH} \mathrm{NOE}$ and a high $d \delta / d T$ value of Aib(3) $\mathrm{NH}$ in $\mathrm{E}_{1.8}$ could, in fact, be rationalized in terms of a partially unfolded conformation when $\psi_{\mathrm{Phe}}-120^{\circ}$, but $\mathrm{Aib}(2) \phi, \psi$ fall in the right-handed helical region $\left(\phi^{-}-60^{\circ}, \psi \sim-30^{\prime}\right)$ such that the N-terminal $\beta$-turn is disrupted.

\section{CONCLUSIONS}

The spectral studies described in this report reaffirm the overwhelming tendency of Aib residues to promote helical folding. Sequence-dependent conformational variability has also been noted, raising questions regarding the sense of helical folding and solvent effects for the Aib peptide antibiotics that possess an N-terminal L-residue. Mitochondria1 uncoupling activity observed for some of these relatively short hydrophobic peptides must reflect their ability to associate in the lipid phase and alter transmembrane permeabilities. The relatively low activity observed for the peptide $\mathbf{E}_{1-10}$, which possesses a terminal Hyp group, suggests that appreciable insertion of peptides into the membrane may be necessary before uncoupling activity is manifested in the case of the short sequences. 
We are grateful to Professor Claudio Toniolo, University of Padova, Italy, for kindly providing the amino acid analyses, and to Mr. S. Raghothama, Sophisticated Instruments Facility, Indian Institute of Science, Bangalore, for his help with the NOE experiments. This research was supported by a grant from the Department of Science and Technology, Government of India. P.A.R. was supported by a Teacher-Fellowship of the University Grants Commission.

\section{References}

1. Argoudelis, A. D. \&Johnson, L. E. (1974) J. Antibiot. 27, 274-282.

2. Pandey, R. C., Carter Cook, J., Jr. \& Rinehart, K. L., Jr. (1977) J. Am. Chem. Soc. 99, 5205-5206.

3. Mueller, P. \& Rudin, D. O. (1968) Nature 217, 713-719.

4. Nagaraj, R. \& Balaram, P. (1981) Acc. Chem. Res. 14, 356-362.

5. Jung, G., Brückner, H. \& Schmitt, H. (1981) in Structure and Actioity of Natural Peptides, Voelter, W. and Weitzel, G., Eds., Walter de Gruyter, Berlin, pp. 75-114.

6. Mathew, M. K. \& Balaram, P. (1983) Mol. Cell. Biochem. 50, 47-64.

7. Prasad, B. V. V. \& Balaram, P. (1984) CRC Crit. Revs. Biochem. 16, 307-348.

8. Schmitt, H. \& Jung, G. (1985) Liebigs Ann. Chem. 1985, 321-344.

9. Hall, J. E., Vodyanoy, I., Balasubramanian, T. M. \& Marshall, G. R. (1984) Biophys. J.45, 233-247.

10. Menestrina, G., Voges, K.-P., Jung, G. \& Boheim, G. (1986) J. Membr. Bwl. 93, 111-132.

11. Balasubramanian, T. M., Redlinski, A. S. \& Marshall, G. R. (1981) in Peptides: Synthesis Structure and Function, Proceedings of the Seventh American Peptide Symposium, Rich, D. H. and Gross, E., Eds., Pierce Chemical Co., Rockford, IL, pp. 61-64.

12 Benedetti, E., Bavoso, A., DiBlasio, B., Pavone, V., Pedone, C., Toniolo, C. \& Bonora, G. M. (1982) Proc. Natl. Acad. Sci. USA 79,7951-7954.

13. Toniolo, C., Bonora, G. M., Bavoso, A., Benedetti, E., DiBlasio, B., Pavone, V. \& Pedone, C. (1985) J. Biomol. Struct. Dynam. 3, 585-598.

14. Bavoso, A., Benedetti, E., DiBlasio, B., Pavone, V., Pedone, C., Toniolo, C. \& Bonora, G. M. (1986) Proc. Natl. Acad. Sci. USA 83, 1988b-1992.

15. Bardi, R., Piazzesi, A. M., Toniolo, C., Raj, P. A., Raghothama, S. \& Balaram, P. (1986) Znt. J. Biol. Macromol. 8, 201-206.

16. Toniolo, C., Bonora, G. M., Benedetti, E., Bavoso, A., DiBlasio, B., Pavone, V. \& Pedone, C. (1985) Znt. J. Biol. Macromol. 7, 357-362.

17. Toniolo, C., Bonora, G. M., Benedetti, E., Bavoso, A., DiBlasio, B., Pavone, V. \& Pedone, C. (1983) Biopolymers 22,1335-1356.

18. Nagaraj, R. \& Balaram, P. (1979) Biochem. Biophys. Res. Commun. 89, 1041-1049.

19. Nagaraj, R. \& Balaram, P. (1981) Tetrahedron 37,2001-2005.

20. Vijayakumar, E. K. S. \& Balaram, P. (1983) Tetrahedron 39, 2725-2731.

21. Rao, B. N. N., Kumar, A., Balaram, H., Ravi, A. \& Balaram, P. (1983) J. Am. Chem. Soc. 105, 7423-7428,

22. Vijayakumar, E. K. S. \& Balaram, P. (1983) Biopolymers 22, 2133-2140.

23. Das, M. K., Basu, A. \& Balaram, P. (1985) Biochem. Intl. 11, 357-363.

24. Wuthrich, K. (1976) NMR in Biological Research: Peptides and Proteins, North-Holland, Amsterdam.

25. Kessler, H. (1982) Angew. Chem. Znt. Ed. Engl. 21, 512-523.

26. Nagaraj, R. \& Balaram, P. (1981) Biochemistry 20, 2828-2835.

27. Iqbal, M. \& Balaram, P. (1981) J. Am. Chem. Soc. 103, 5548-5552.

28. Iqbal, M. \& Balaram, P. (1981) Biochemistry 20, 4866-4871.

29. Balaram, H., Sukumar, M. \& Balaram, P. (1986) Biopolymers 25,2209-2223.

30. Bystrov, V. F. (1976) Prog. NMR Spectrosc. 10, 41-81.

31. Stevens, E. S., Sugawara, N., Bonora, G. M. \& Toniolo, C. (1980) J. Am. Chem. Soc. 102, 7048-7050,

32. Iqbal, M. \& Balaram, P. (1981) Biochemistry 20, 7278-7284.

33. Iqbal, M. \& Balaram, P. (1982) Biopolymers 21, 1427-1433.

34. Rao, Ch. P., Nagaraj, R., Rao, C. N. R. \& Balaram, P. (1979) FEBS Lett. 100, 244-248.

35. Rao, Ch., P., Nagaraj, R., Rao, C. N. R. \& Balaram, P. (1980) Biochemistry 19, 425-431. 
36. Benedetti, E., Bavoso, A., DiBlasio, B., Pavone, V., Pedone, C., Crisma, M., Bonora, G. M. \& Toniolo, C. (1982) J. Am. Chem. Soc. 104, 2437-2444.

37. Toniolo, C., Bonora, G. M., Barone, V., Bavoso, A., Benedetti, E., DiBlasio, B., Grimaldi, P., Lelj, F., Pavone, V. \& Pedone C. (1985) Macromolecules 18, 895-902.

38. Balaram, P. (1983) in Peptides: Structure and Function, Proceedings of the Eighth American Peptide Symposium, Hruby, V. J. \& Rich, D. H., Eds., Pierce Chemical Co., Rockford, IL, pp. 477-486.

39. Bosch, R., Jung, G., Schmitt, H. \&Winter, W. (1985) Biopolymers 24, 961-978.

40. Bosch, R., Jung, G., Schmitt, H. \&Winter, W. (1985) Biopolymers 24, 979-999.

41. Karle, I. L., Sukumar, M. \& Balaram, P. (1986) Proc. Natl. Acad. Sci. USA 83,9284-9288

42. Karle, I. L., Flippen-Anderson, J. L., Sukumar, M. \& Balaram, P. (1987) Proc. Natl. Acad. Sci. USA 84, 5087-5091.

43. Rose, G. D., Gierasch, L. M. \& Smith, J. A. (1985) Adv. Protein Chem. 37, 1-109.

44. Das, M. K., Raghothama, S. \& Balaram, P. (1986) Biochemistry 25, 7110-7117.

45. Wuthrich, K., Billeter, M. \& Braun, W. (1984) J. Mol. Biol. 180, 715-740.

46. Shenderovich, M. D., Nikiforovich, G. V. \& Chipens, G. I. (1984) J. Magn. Reson. 59, 1-12.

47. Balaram, P., Bothner-By, A. A. \& Dadok, J. (1972) J. Am. Chem. Soc. 94, 4015-4016.

48. Ramachandran, G. N. \& Sasisekharan, V. (1968) Ado. Protein Chem. 23, 283-437. 